\title{
backstory
}

\section{Shifting sands}

\section{David Rubin and Patrick Hesp spent a night in a labour camp come hotel while trying to uncover the factors that shape sand dunes in the Qaidam Basin, China.}

\section{What was the objective of the work?} Initially, we wanted to determine how wind flow shapes sand dunes in the Qaidam Basin, China. Along the way, we found that the Qaidam Basin dunes have migrated laterally, but not in a consistent direction. Following this discovery, we shifted the focus of our work to try to understand why unidirectional winds in this region produce dunes with long straight crests that are aligned roughly parallel to the wind; in most deserts on Earth, such winds produce dunes with less continuous curved crests that are oriented perpendicular to the wind.

\section{Did you encounter any difficulties?} After we had travelled nearly halfway around the world to visit the field site, the driver of our vehicle absolutely refused to drive off the surfaced road. Eventually, our interpreter explained to us that the driver was personally liable for maintaining his vehicle, and that merely having to replace a tire could cost him a month's wages. Once we offered to pay for repairs, the driver agreed to drive off-road into the dune field. Then, on our first excursion off-road, the vehicle became mired down in soft sediment, which caused delays and much shouting in various languages, but no damage to the vehicle. Logistical arrangements were also tricky. Because we were working in a region closed to foreigners travelling on their own, we were assigned government hosts, escorts, a driver and a translator. Our hosts at the Institute of Desert Research in Lanzhou sent someone to the town nearest our field site before our arrival, armed with a few thousand dollars in cash and a revolver for protection. One night he arranged for us to sleep in the cells of a labour camp that had been used during the Cultural Revolution. It was being converted to a hotel but did not have any water yet.

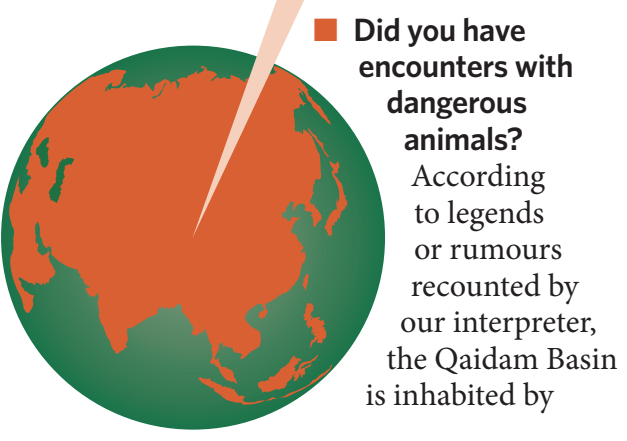

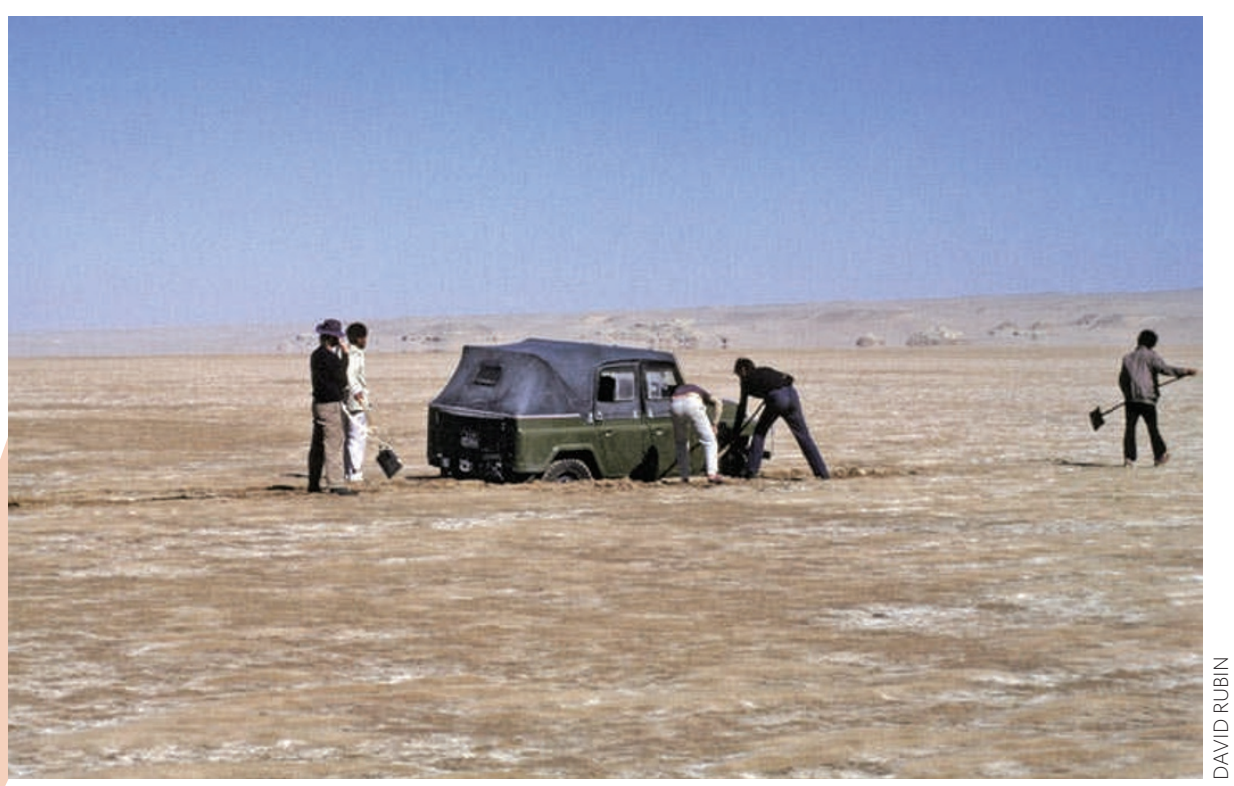

On our first off-road excursion, our field vehicle sank into the sediment. Although the ground surface looks dry, water is present just below the surface, and the sediment is soft and fluid

wolves, but the extreme climate and salty groundwater keep the area nearly devoid of plant and animal life. In our two weeks there, the only animals we saw were a sheep skeleton, a dead bird and one live, burrowing, gerbil-like animal.

\section{Any low points?}

We obtained our field provisions at local markets near the field area, and the packaged goods were all labelled in Chinese. We found cans that pictured an athlete logo, and, thinking it was the perfect drink for desert fieldwork, purchased several dozen of these. Unfortunately, what we thought was a sports drink turned out to be a lychee mix that was too syrupy to be refreshing. And Patrick Hesp became violently ill after drinking tea made from water we had boiled in an aluminium pot.

\section{What was the highlight of the} expedition?

Seeing a sandstorm was the chance of a lifetime for someone interested in sand. It stripped loose sand off the bed, exposed large expanses of internal stratification and allowed us to see local accumulations of new sand. However, the storm stirred up so much sand and dust into the air that the daytime sky turned dark, breathing became difficult without a dust mask and tents were flattened. My tent pole was broken during the windstorm, and I had to spend an uncomfortable night trying to keep the rest of the tent intact. And my camera accumulated so much wind-borne dust that it needed professional cleaning after the trip. We also got to visit an historic Buddhist monastery on our travels to our field area on the Tibetan plateau.

Did the trip give you any ideas for future research projects?

We now want to see whether there is an example of a dune field where unidirectional winds are actively creating longitudinal dunes - which elongate parallel to the prevailing wind - in loose unstabilized sand; if so, we want to know why dunes form in this way. We also want to know what controls the height and spacing of linear dunes in cohesive sediment.

This is the Backstory to the work by David Rubin and Patrick Hesp, published on page 653 of this issue. 